\title{
BMC Medicine: a decade of open access medical research
}

\author{
Sabina Alam ${ }^{*}$ and Jigisha Patel
}

\begin{abstract}
On 24 November 2003, BMC Medicine published its first article. Ten years and over 900 articles later we look back at some of the most notable milestones for the journal and discuss advances and innovations in medicine over the last decade. Our editorial board members, Leslie Biesecker, Thomas Powles, Chris Del Mar, Robert Snow and David Moher, also comment on the changes they expect to see in their fields over the coming years.
\end{abstract}

Keywords: Open access, Translational medicine, Clinical oncology, Evidence-based medicine, Reporting guidelines

\section{Editorial}

Just a few months after the Human Genome Project was declared complete [1] BMC Medicine was launched as an open access $[2,3]$, open peer review journal (i.e. where signed peer review reports are published with the article) $[4,5]$, with the aim of making high impact clinical peer-reviewed research of general interest, accessible to everyone from the basic scientist to the practicing clinician. The journal, initially under the direction of Pritpal Tamber and then Melissa Norton as Editor-inChief, was launched amidst a raging debate about the viability of open access publishing [6]. But open access survived and evolved [7,8], and BMC Medicine now ranks $8^{\text {th }}$ out of 155 journals in the 2012 general and internal medical journals category of the Journal Citation Reports [9].

While mainly focused on primary research in its early days, the journal responded to the needs and demands of its readers and contributors by providing, for example, a platform for discussing controversies in medical practice [10-15] and embracing social networking technology to promote open scientific discussion and debate [16-19]. Although proud of its Impact Factor (IF) of 6.68, BMC Medicine recognizes that the IF is a restrictive metric that does not fully reflect the

\footnotetext{
* Correspondence: Sabina.Alam@biomedcentral.com

BioMed Central Ltd, 236 Gray's Inn Road, London WC1X 8HB, UK
}

influence of individual articles post-publication. The journal therefore provides informative article metrics which are immediately available on published articles a feature which has proven to be popular with many of our authors [20].

Of course, innovations in publishing and technical advances notwithstanding, BMC Medicine owes its success to the scientific contributions made by its authors, reviewers and expert editorial board members. To celebrate its $10^{\text {th }}$ anniversary, we recently reviewed some of our most successful articles in terms of accesses [21], citations [22] and 'impact' in news and social media [23], and also summarized author and reviewer experiences [24] and explored our author demographics [25]. As a general medical journal with a very broad scope, it is not possible for us to cover all the main advances in medicine featured in the journal over the last decade, but in this editorial we present a selection of our favorite recent content, together with predictions by our editorial board members on possible future directions for their respective fields of research.

\section{Translational medicine: how far have we come with stem cells, biomarkers and 'Omics' research?} Stem cell research and therapy has advanced rapidly in the last decade, and clinical trials for a wide range of diseases are already underway [26,27]. In 2012, the journal published an intriguing study by Zhao and colleagues, who used Stem Cell Educator therapy to 
safely reverse Type 1 diabetes. The researchers used stem cells from cord blood to 're-educate' $\mathrm{T}$ cells in patients with Type 1 diabetes, thereby restoring pancreatic function and reducing the need for insulin [28]. These compelling results highlight how stem cell therapies may become part of mainstream treatment for many diseases.

Within the last 10 years, major advances have also been made in biomarker research and 'Omics' studies in a preclinical setting. Advances in whole genome sequencing have allowed the identification of genes involved in a large number of diseases, and biomarkers that indicate disease severity or susceptibility to treatment are increasingly being characterized [29-32]. As Leslie Biesecker points out (Box 1), clinical exome and genome sequencing are already being used in the clinic for diagnostic and prognostic purposes. However, Biesecker also indicates that these new technologies are not without problems and alludes to the role the journal plays in ensuring the latest research is appropriately validated and disseminated.

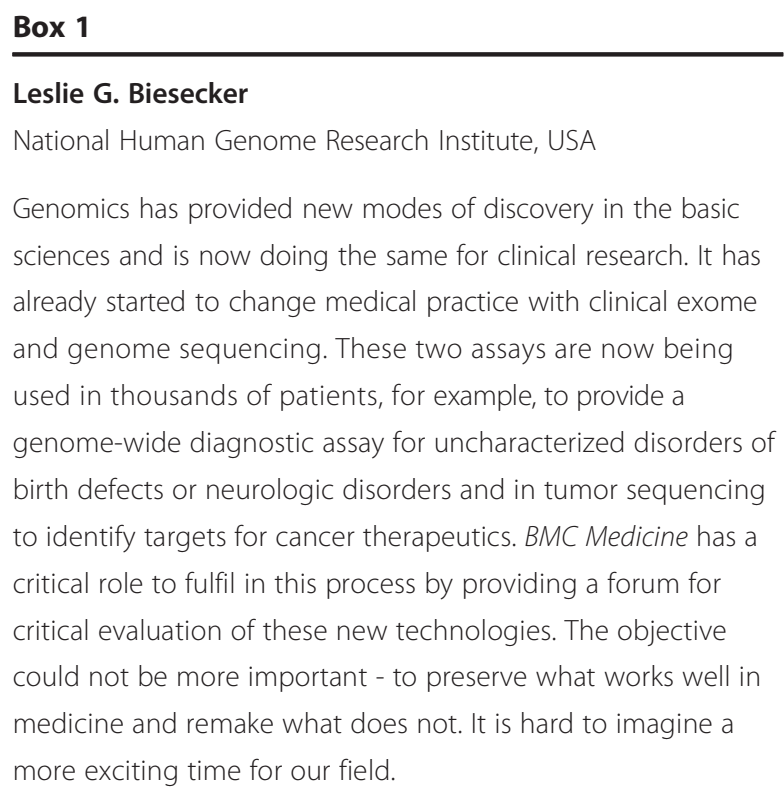

Despite the discovery of many biomarkers for cancer in particular, so far very few have been used within the clinical setting [33], which is partly due to a lack of consistency and clarity in the reporting of prognostic tumor markers. This prompted the development of the Reporting Recommendations for Tumor Marker Prognostic Studies (REMARK) checklist [34], which was updated in 2012 by Altman and colleagues [35] and more recently, the development of criteria to address the lack of scientific rigor when evaluating preclinical evidence to support translation of omics-based predictors to clinical trials $[36,37]$.

The continued identification of new genes and biomarkers specific to disease subtypes and individual patients is essential for translation into personalized medicine, in terms of estimating both disease risk and response to therapy. As highlighted above, the field which has seen the most progress in this area is clinical oncology, and Thomas Powles explains what further changes are required to achieve effective personalized cancer therapies (Box 2).

\section{Box 2 \\ Thomas Powles \\ St Bartholomew's Hospital, London, UK \\ The field of medical oncology is moving at a breathtaking \\ speed. A plethora of new agents are now available based on the molecular biology of specific tumors. The next step is to identify subsets of patients who benefit from therapy and move away from 'one size fits all' strategies. Therefore, biomarkers predicting response to these therapies are required. The application of whole genome sequencing, novel tracers within the context of functional imaging and circulating biomarkers, such as free circulating tumor DNA will be important pieces in this complex puzzle. There is also a need to develop therapies which focus on inducing longer remission rather than temporary disease controls. \\ A collaborative international approach is required to achieve these goals.}

\section{Evidence-based medicine: education, communication and collaboration}

There has been increasing international focus on public health initiatives, development of healthcare policies and evidence-based guidelines to improve medical practice $[38,39]$. This is embedded in effective education strategies, which is evident from a continuing medical education intervention aimed at strengthening links between evidence-based and values-based medicine in healthcare personnel [40]. Researchers found this intervention led to improved values, such as openness to change, which are essential for improving medical care. 
Chris Del Mar (Box 3) recommends that going forward a more collaborative approach to decision-making between clinicians, patients and policy makers needs to be developed, and highlights the importance of transparency and communication.

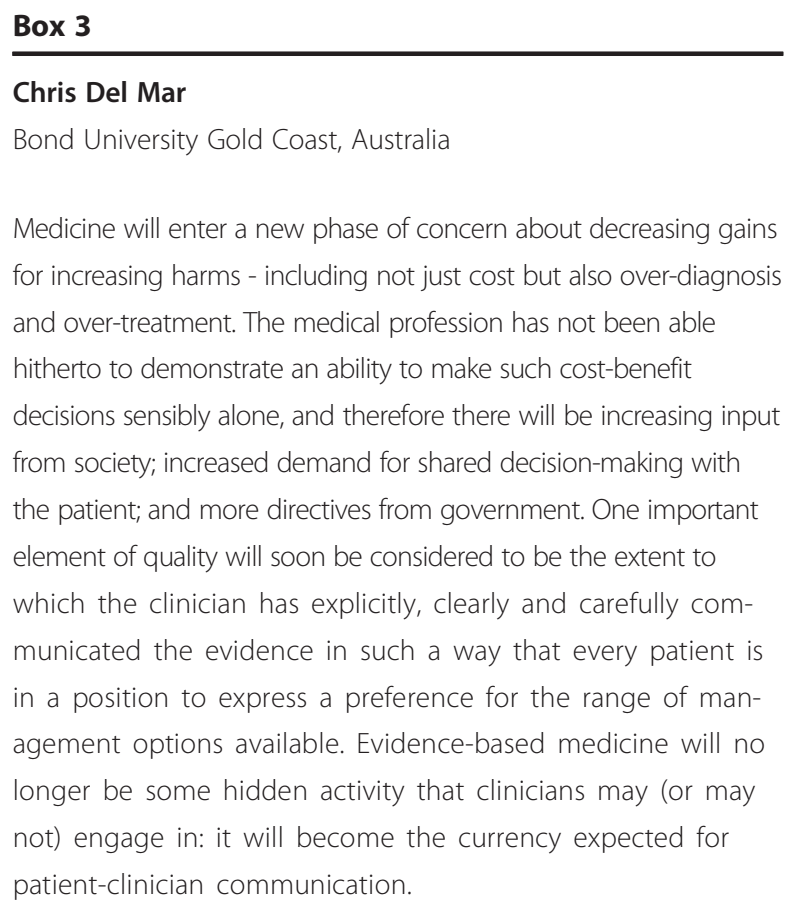

There is also increasing focus on involving researchers based in low-to-middle income countries as principal investigators in local research projects. This is especially important as local knowledge helps to ask the 'right' questions in health research, ensures the best available evidence is accumulated and that all ethical aspects have been considered [41-43]. This is vital to guide healthcare policies and identify new tools and strategies; the consequences of not doing so is evident from a recent bibliometric analysis of childhood immunization research output from Africa. Since the onset of the Expanded Program on Immunization in 1974, vaccine research productivity in Africa has skewed toward those funded privately, with minimal research input from African authors, suggesting a need for better communication among all stakeholders [44]. Robert Snow points out (Box 4), conditions for research are now improving in Africa, and it is important that local researchers and governments work closely to drive the research output from these regions forward.

\begin{abstract}
Box 4
Robert William Snow

Kenya Medical Research Institute, Kenya

Since I started work in Africa 30 years ago the landscape of science and research capacity has changed enormously. It is no longer legitimate to make excuses that model-based computing, laboratory science or gene sequencing can only be done in the north. The infrastructure and human capacity now exists in Africa to provide the best possible science for public health problems that face the continent. A fundamental requirement for any form of development is that countries have to take ownership of their problems. The next decade requires an active promotion by governments in Africa, and international partners that support regional development, of the expanding cohorts of African scientists who champion the very highest standards of medical and public health science within the region. Generating new research from within Africa holds untold promise. Unlike external research agendas and funding 30 years ago, this new research will have a much greater and much faster impact on the health of communities in Africa over the next decade.
\end{abstract}

\section{Enhancing research with reporting guidelines}

Without clear guidelines for conducting and analyzing medical research, there is a limit to how far medicine can progress, and the last few years have seen many important improvements in reporting standards. In 2010, BMC Medicine co-published the updated CONSORT (CONsolidated Standards of Reporting Trials) statement by Schulz and colleagues [45]. This statement guides authors on the reporting of two-parallel design randomized controlled trials by using a checklist and flow diagram based on the latest methodological evidence. More recently, in response to the particular challenges in reporting economic evaluations of health interventions, the Consolidated Health Economic Evaluation Reporting Standards (CHEERS) was published [46]. This statement consolidates existing guidelines with the aim of providing more 'user-friendly' guidance for researchers and editors.

As research methods become more sophisticated, so too do the methods via which literature analysis can be conducted. The 'RAMESES' (Realist and Meta-review Evidence Synthesis: Evolving Standards) statement $[47,48]$ was published to provide researchers, institutes and journals with guidance on how to conduct these new forms of literature analysis, and adherence to the guidelines will lead to quality assurance and uniform reporting of studies. 
Ensuring consistency is a challenging task, and David Moher explains (Box 5) that journals and editors play a key role in providing peer reviewers and authors with the tools and guidance to ensure that medical research is appropriately reported.

Box $\mathbf{5}$
David Moher
Ottawa Hospital Research Institute, Canada
To reduce the considerable waste of inadequately published
research, medical journals will need to develop long-term innovative
strategies, such as developing core competencies for editors and
peer reviewers, as well as accreditation programs for journals. More
immediately, they can help foster greater implementation of
reporting guidelines by facilitating the development of applications
that can take manuscript content and automatically populate
reporting guideline checklists. Such information can provide
immediate feedback about the completeness of reporting of
manuscripts to authors, editors and peer reviewers.

We hope you have enjoyed our selection of just some of the most exciting content from BMC Medicine, and hope this has prompted you to seek out favorites of your own.

As an open access general medical journal, we aim to promote better informed clinical decisions and improved therapies. We will continue to publish content that has the potential to improve clinical practice, research and reporting. We especially encourage debate on health related issues not just within the clinical community, but also for the general public who should be, after all, the primary beneficiaries of the research.

\section{Competing interests}

Both authors are employees of BioMed Central, the publisher of BMC Medicine.

\section{Authors' information}

Sabina Alam is the Editor of BMC Medicine. Jigisha Patel is the Medical Editor at BioMed Central.

\section{Acknowledgements}

We thank our academic editorial board and our reviewers for the contribution they have made to the success of BMC Medicine and our authors and readers for their ongoing support.

Received: 18 December 2013 Accepted: 18 December 2013 Published: 09 Jan 2014

\section{References}

1. Collins FS, Green ED, Guttmacher AE, Guyer MS: A vision for the future of genomics research: a blueprint for the genomic era. Nature 2003, 422:1-13.

2. Tamber PS, Godlee F, Newmark P: Open access to peer-reviewed research: making it happen. Lancet 2003, 362:1575-1577.
3. Suber P: Open Access. Cambridge, MA: MIT Press; 2012.

4. BMC Medicine: Publication and peer review process. http://www. biomedcentral.com/bmcmed/about\#publication.

5. Godlee F: Making reviewers visible: openness, accountability, and credit JAMA 2002, 287:2762-2765

6. Solomon DJ: Talking past each other: making sense of the debate over electronic publication. First Monday 2002, 7. http://dx.doi.org/10.5210\% 2Ffm.v7i8.978.

7. Björk B-C, Solomon DJ: Open access versus subscription journals - a comparison of scientific impact. BMC Med 2012, 10:73.

8. Laakso M, Björk B-C: Anatomy of open access publishing: a study of longitudinal development and internal structure. BMC Med 2012, 10:124.

9. Journal Citation Reports ${ }^{\circledast} 2013$ Release. http://wokinfo.com/ products_tools/analytical/jcr/.

10. Greenhalgh T, Swinglehurst D: Studying technology use as social practice: the untapped potential of ethnography. BMC Med 2011, 9:45.

11. Autier $\mathrm{P}$, Boniol $\mathrm{M}$ : Breast cancer screening: evidence of benefit depends on the method used. BMC Med 2012, 10:163.

12. Puliti D, Zappa M: Breast cancer screening: are we seeing the benefit? BMC Med 2012, 10:106

13. Franco R, Saag MS: When to start antiretroviral therapy: as soon as possible. BMC Med 2013, 11:147.

14. Lundgren JD, Babiker AG, Gordin FM, Borges ÁH, Neaton JD: When to start antiretroviral therapy: the need for an evidence base during early HIV infection. BMC Med 2013, 11:148.

15. Nemeroff CB, Weinberger D, Rutter M, MacMillan HL, Bryant RA, Wessely $\mathrm{S}$, Stein DJ, Pariante CM, Seemüller F, Berk M, Malhi GS, Preisig M, Brüne M, Lysaker P: DSM-5: a collection of psychiatrist views on the changes, controversies, and future directions. BMC Med 2013, 11:202.

16. Timimi FK: Medicine, morality and health care social media. BMC Med 2012, 10:83.

17. Social media in healthcare. http://storify.com/BMCMedicine/draft-storify

18. The growth of open access journals. http://storify.com/BMCMedicine/ oaweek2012.

19. Open access, medical research and global health. http://blogs. biomedcentral.com/bmcblog/2013/10/25/open-access-medical-researchand-global-health-a-bmc-medicine-twitter-chat/.

20. BMC Medicine article metrics FAQ. http://www.biomedcentral.com/ bmcmed/about/articlemetrics.

21. Barnard C: BMC Medicine's top 10 most accessed articles. http://blogs biomedcentral.com/bmcblog/2013/11/25/bmc-medicines-top-10-mostaccessed-articles/.

22. Alam S: BMC Medicine: our ten most highly cited articles. http://blogs. biomedcentral.com/bmcblog/2013/11/26/bmc-medicine-our-10-mosthighly-cited-articles/.

23. Denyer J: Impact of BMC Medicine articles in the news and social media. http://blogs.biomedcentral.com/bmcblog/2013/11/27/impact-of-bmcmedicine-articles-in-the-news-and-social-media/.

24. D'Souza U: BMC Medicine: authors and reviewers experiences. http:// blogs.biomedcentral.com/bmcblog/2013/11/28/bmc-medicine-authorsand-reviewers-experiences/.

25. Lee L: Demographics over the past 10 years - where are our authors based? http://blogs.biomedcentral.com/bmcblog/2013/11/29/ demographics-over-the-past-10-years-where-are-our-authors-based/.

26. Trounson A, Thakar RG, Lomax G, Gibbons D: Clinical trials for stem cell therapies. BMC Med 2011, 9:52.

27. Politis $M$, Lindvall $O$ : Clinical application of stem cell therapy in Parkinson's disease. BMC Med 2012, 10:1.

28. Zhao $Y$, Jiang Z, Zhao T, Ye M, Hu C, Yin Z, Li H, Zhang Y, Diao Y, Li Y, Chen $Y$, Sun X, Fisk MB, Skidgel R, Holterman M, Prabhakar B, Mazzone T: Reversal of type 1 diabetes via islet $\beta$ cell regeneration following immune modulation by cord blood-derived multipotent stem cells. BMC Med 2012, 10:3

29. Warren JD, Xiong W, Bunker AM, Vaughn CP, Furtado LV, Roberts WL, Fang JC, Samowitz WS, Heichman KA: Septin 9 methylated DNA is a sensitive and specific blood test for colorectal cancer. BMC Med 2011, 9:133.

30. Hsu YC, Chen HY, Yuan S, Yu SL, Lin CH, Wu G, Yang PC, Li KC: Genome-wide analysis of three-way interplay among gene expression, cancer cell invasion and anti-cancer compound sensitivity. BMC Med 2013, 11:106.

31. Brothers JF, Hijazi K, Mascaux C, El-Zein RA, Spitz MR, Spira A: Bridging the clinical gaps: genetic, epigenetic and transcriptomic biomarkers for the 
early detection of lung cancer in the post-National Lung Screening Trial era. BMC Med 2013, 11:168.

32. Liu LY, Yang T, Ji J, Wen Q, Morgan AA, Jin B, Chen G, Lyell DJ, Stevenson DK, Ling XB, Butte AJ: Integrating multiple 'omics' analyses identifies serological protein biomarkers for preeclampsia. BMC Med 2013, 11:236.

33. Diamandis EP: The failure of protein cancer biomarkers to reach the clinic: why, and what can be done to address the problem? BMC Med 2012, 10:87.

34. McShane LM, Altman DG, Sauerbrei W, Taube SE, Gion M, Clark GM, Statistics Subcommittee of the NCI-EORTC Working Group on Cancer Diagnostics: REporting recommendations for tumour MARKer prognostic studies (REMARK). Br J Cancer 2005, 93:387-391.

35. Altman DG, MCShane LM, Sauerbrei W, Taube SE: Reporting recommendations for tumor marker prognostic studies (REMARK): explanation and elaboration. BMC Med 2012, 10:51.

36. McShane LM, Cavenagh MM, Lively TG, Eberhard DA, Bigbee WL, Williams PM, Mesirov JP, Polley MY, Kim KY, Tricoli JV, Taylor JM, Shuman DJ, Simon RM, Doroshow JH, Conley BA: Criteria for the use of omics-based predictors in clinical trials. Nature 2013, 502:317-320.

37. McShane LM, Cavenagh MM, Lively TG, Eberhard DA, Bigbee WL, Williams PM, Mesirov JP, Polley MY, Kim KY, Tricoli JV, Taylor JM, Shuman DJ, Simon RM, Doroshow JH, Conley BA: Criteria for the use of omics-based predictors in clinical trials: explanation and elaboration. BMC Med 2013, 11:220.

38. Birbeck G: Medicine for global health: can "simple interventions" improve the worldwide burden of disease? BMC Med 2013, 11:72.

39. Birbeck G, Wiysonge CS, Mills EJ, Frenk JJ, Zhou XN, Jha P: Global health: the importance of evidence-based medicine. BMC Med 2013, 11:223.

40. Altamirano-Bustamante MM, Altamirano-Bustamante NF, Lifshitz A, Mora-Magaña I, de Hoyos A, Avila-Osorio MT, Quintana-Vargas S, Aguirre JA, Méndez J, Murata C, Nava-Diosdado R, Martínez-González O, Calleja E, Vargas R, Mejía-Arangure JM, Cortez-Domínguez A, Vedrenne-Gutiérrez F, Sueiras P, Garduño J, Islas-Andrade S, Salamanca F, Kumate-Rodríguez J, Reyes-Fuentes A: Promoting networks between evidence-based medicine and values-based medicine in continuing medical education. BMC Med 2013, 11:39.

41. Jacob ST, Lim M, Banura P, Bhagwanjee S, Bion J, Cheng AC, Cohen H, Farrar J, Gove S, Hopewell P, Moore CC, Roth C, West TE: Integrating sepsis management recommendations into clinical care guidelines for district hospitals in resource-limited settings: the necessity to augment new guidelines with future research. BMC Med 2013, 11:107.

42. Burgess Pl, Msukwa G, Beare NA: Diabetic retinopathy in sub-Saharan Africa: meeting the challenges of an emerging epidemic. BMC Med 2013, 11:157.

43. Giordano J: Ethical considerations in the globalization of medicine - an interview with James Giordano. BMC Med 2013, 11:69.

44. Wiysonge CS, Uthman OA, Ndumbe PM, Hussey GD: A bibliometric analysis of childhood immunization research productivity in Africa since the onset of the Expanded Program on Immunization in 1974. BMC Med 2013, 11:66

45. Schulz KF, Altman DG, Moher D, CONSORT Group: CONSORT 2010 Statement: updated guidelines for reporting parallel group randomised trials. BMC Med 2010, 8:18

46. Husereau D, Drummond M, Petrou S, Carswell C, Moher D, Greenberg D, Augustovski F, Briggs AH, Mauskopf J, Loder E, CHEERS Task Force: Consolidated Health Economic Evaluation Reporting Standards (CHEERS) statement. BMC Med 2013, 11:80.

47. Wong G, Greenhalgh T, Westhorp G, Buckingham J, Pawson R: RAMESES publication standards: meta-narrative reviews. BMC Med 2013, 11:20.

48. Wong G, Greenhalgh T, Westhorp G, Buckingham J, Pawson R: RAMESES publication standards: realist syntheses. BMC Med 2013, 11:21.

10.1186/1741-7015-12-4

Cite this article as: Alam and Patel: BMC Medicine: a decade of open access medical research. BMC Medicine 2014, 12:4

\section{Submit your next manuscript to BioMed Central and take full advantage of:}

- Convenient online submission

- Thorough peer review

- No space constraints or color figure charges

- Immediate publication on acceptance

- Inclusion in PubMed, CAS, Scopus and Google Scholar

- Research which is freely available for redistribution

Submit your manuscript at www.biomedcentral.com/submit
() Biomed Central 